
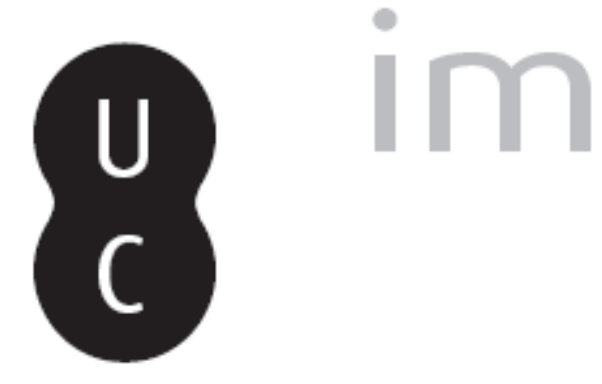

\title{
prartIIIm
}

\section{Entre livros e Eudoro: relato de algumas experiências}

\section{Autor(es): Mota, Marcus}

Publicado por: Annablume Clássica; Imprensa da Universidade de Coimbra

URL persistente:

URI:http://hdl.handle.net/10316.2/24342

DOI:

DOI:http://dx.doi.org/10.14195/1984-249X_8_6

Accessed : $\quad$ 26-Apr-2023 13:34:18

A navegação consulta e descarregamento dos títulos inseridos nas Bibliotecas Digitais UC Digitalis, UC Pombalina e UC Impactum, pressupõem a aceitação plena e sem reservas dos Termos e Condições de Uso destas Bibliotecas Digitais, disponíveis em https://digitalis.uc.pt/pt-pt/termos.

Conforme exposto nos referidos Termos e Condições de Uso, o descarregamento de títulos de acesso restrito requer uma licença válida de autorização devendo o utilizador aceder ao(s) documento(s) a partir de um endereço de IP da instituição detentora da supramencionada licença.

Ao utilizador é apenas permitido o descarregamento para uso pessoal, pelo que o emprego do(s) título(s) descarregado(s) para outro fim, designadamente comercial, carece de autorização do respetivo autor ou editor da obra.

Na medida em que todas as obras da UC Digitalis se encontram protegidas pelo Código do Direito de Autor e Direitos Conexos e demais legislação aplicável, toda a cópia, parcial ou total, deste documento, nos casos em que é legalmente admitida, deverá conter ou fazer-se acompanhar por este aviso.

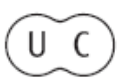


jan.2012

issn $2179-4960$

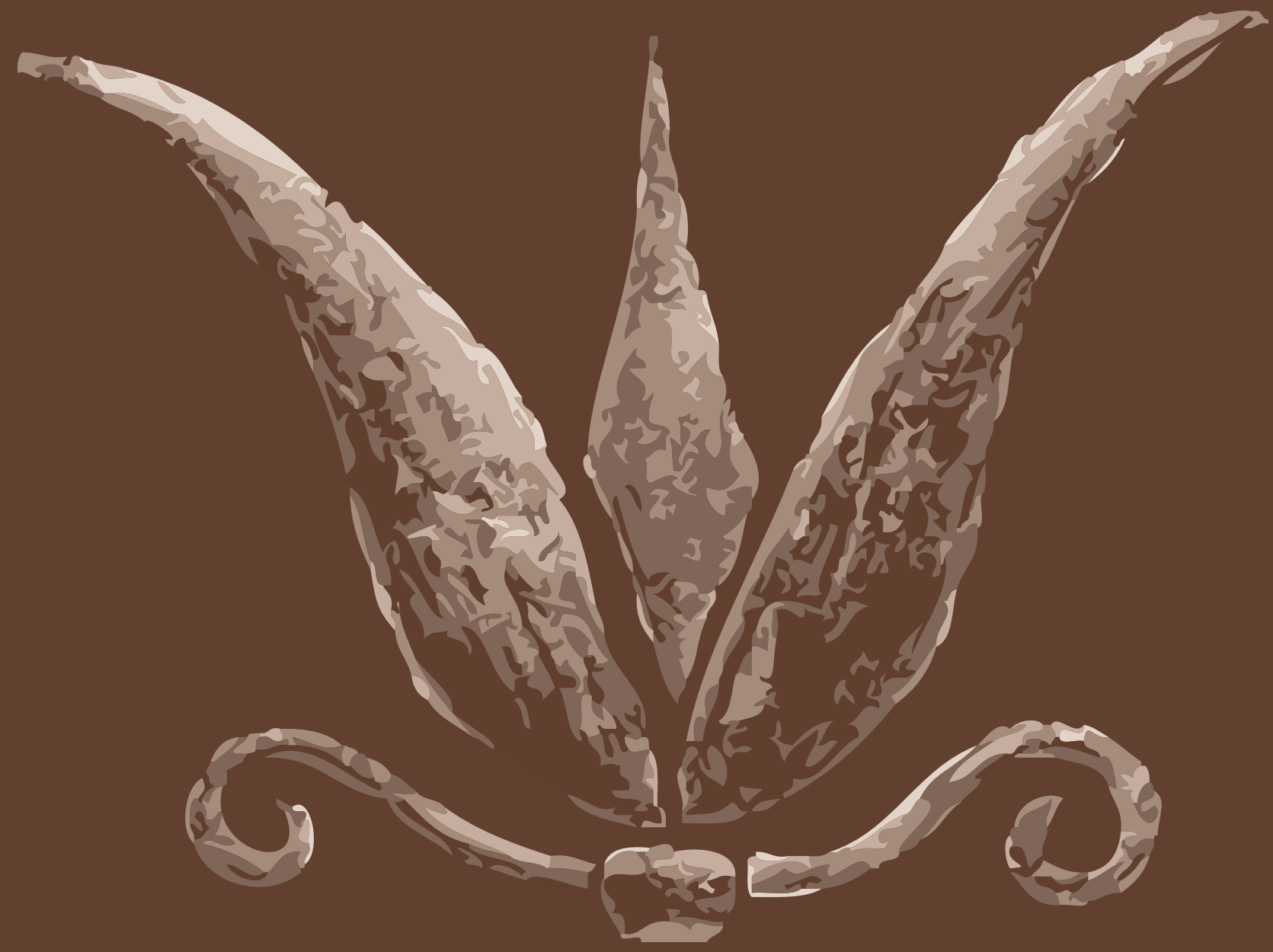

R E V I S T A
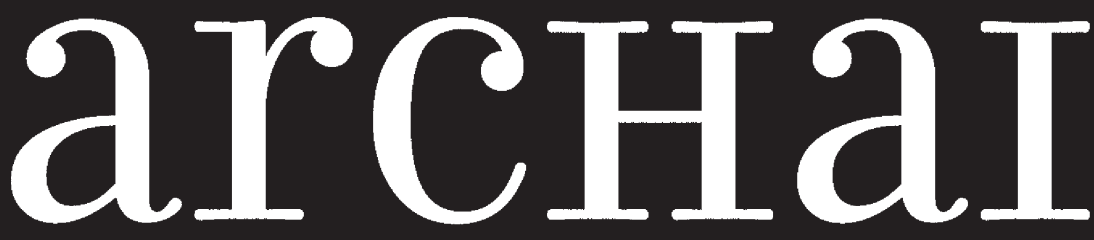

AS ORIGENS DO PENSAMENTO OCIDENTAL

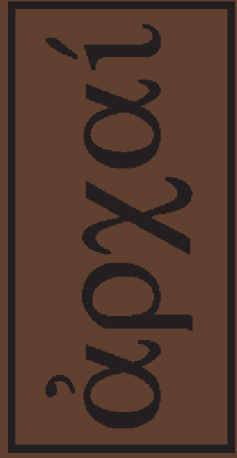

ARCHAI JOURNAL: ON THE ORIGINS OF WESTERN THOUGHT
arcHaI

AS ORIGENS DO PENSAMENTO OCIDENTA.

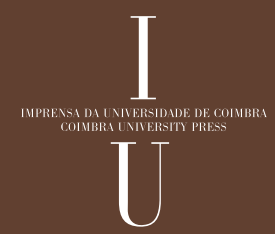

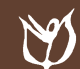




\section{ENTRE LIVROS E EUDORO: RELATO DE ALGUMAS EXPERIÊNCIAS}

MOTA, M. (2012). “Entre livros e Eudoro: relato de algumas experiências". Archai n. 8, jan-jun 2012, pp. 57-74.

RESUMO: 0 que se segue é uma mixagem entre reflexões, memórias e leituras como forma de lançar luz sobre aspectos da recepção da obra de Eudoro de Sousa. Creio que a partir desse experimento multiforme pode-se problematizar não só questões que encontramos nos textos de Eudoro como também como a continuidade de sua presença entre nós.

PALAVRAS-CHAVE: Eudoro de Sousa, Estudos Clássicos, Mitologia, Heráclito.

ABSTRACT: In this paper I present a mix between thoughts, memories and interpretations in order to shed light on the reception of Eudoro de Sousa's works. This hermeneutic and textual strategy produces an academic experiment whose expression emulates not only the multiple aspects of Eudoro de Sousa's texts but also its reception.

KEYWORDS: Eudoro de Sousa, Classics, Mythology, Heraclitus
* Universidade de Brasília. marcusmotaubn@gmail.com www.marcusmota.com.br
Marcus Mota*

Inicialmente, apresento de onde falo como forma de justificar a metodologia empregada neste artigo. Meu contato com a obra de Eudoro de Sousa se iniciou com a leitura de Mitologia (Editora UnB,1980). Isso foi em 1985, um ano antes de eu entrar na Universidade de Brasília (UnB). Aliás, minha decisão de prestar vestibular para a UnB foi a de procurar estudar com Eudoro. 0 fascínio que o livro Mitologia exercia (e exerce) em seus leitores advinha de um momento maduro de Eudoro, uma posição excepcional de scholar dentro do contexto nacional: não só dominava os instrumentos da filologia clássica como também movimentava-se com qualidade no exercício da escrita. Dessa forma, Mitologia era obra de intelectual e de autor. Era uma outra mitologia, não uma história da mitologia, mas uma mitologia dos processos, uma metamitologia.

Tal capacidade de articular um discurso embasado e ao mesmo tempo unir a reflexão ao estilo impunha-se ao leitor como uma abertura gigantesca de horizontes. E tudo isso em língua portuguesa. Eudoro tornava possível e acessível um pensamento que beirava à sublimidade. 0 fascínio em parte vinha dessa ilusão: ao nos projetar na intimidade desse poder pensar, parecia que todos nós pensávamos juntos, éramos também sujeitos dessa reflexão. A metamitologia de Eudoro, que não era tradicional 
narrativa dos mitos nem um puro comentário intelectual dos mesmos, produzia pela leitura essa experiência de compartilhamento de um estado de estímulo ao pensar.

Entrando no curso de letras em 1986, logo vi que o contato com Eudoro era impossível. Ainda o vi um dia pelos corredores do minhocão, levado para alguma reunião ou coisa parecida, frágil, bem diferente do vigor de seus livros. Ele morreu em 1987. Em 1988 comecei a frequentar aulas e encontros de pesquisa com um de seus discípulos, 0 professor Ronaldes de Mello e Sousa, hoje professor na Universidade Federal do Rio de Janeiro ${ }^{1}$.

Com Ronaldes, tive a oportunidade de entrar em contato tanto com muitas das histórias em torno de Eudoro, quanto com o modelo educacional que Eudoro estabeleceu em sua estada na Universidade de Brasília.

Primeiro o modelo: Ronaldes inseria os seus estudantes em uma relação de qualidade com textos. Inicialmente, fazia questão de enfatizar o acesso à bibliografia primária, às obras antes dos comentários às obras. Para tanto, incentivava o estudo das obras em suas línguas originais. Em conjunto a isso, trabaLhava em duas linhas: uma, a da poética das obras, do exame de seus modos de construções, de suas técnicas literárias; a outra, do horizonte das grandes questões, com a leitura e discussão de clássicos da filosofia. Todas essas atividades se davam no interior de um grupo, de uma comunidade de aprendizagem. Mesmo em volta do centro de orientação, cada um desenvolvia um campo de interesses próprio.

$\mathrm{Na}$ realidade, esse grupo de aprendizagem se desdobrava em modos formais e informais de ensino-aprendizagem. De um lado, havia o desenvolvimento de atividades no interior das disciplinas do currículo; de outro, encontros dos integrantes em reuniões fora deste espaço formal. Em outras palavras, as disciplinas da grade curricular eram abertas para todos, enquanto que o espaço informal se destinava a um seleto conjunto de membros.

Nos espaço informal, havia o detido exame de textos fundamentais, como por exemplo o texto platônico do mito da caverna, a carta sétima de Platão, seguindo um pouco ou repertório ou 0 ideal presente em Filosofia Grega, de Eudoro. Com um grupo mais concentrado e aberto à proposta do modelo educacional efetivado, as leituras e os comentários do texto escolhido possibilitavam uma aguçamento dos modos de interpretação, fato muitas vezes difícil nas disciplinas. Na verdade, Ronaldes utilizava-se deste método de cada aula analisar um texto também no espaço formal. A diferença para o espaço informal é o de repertório: enquanto que no espaço formal se seguia um currículo, uma ordem temática ou cronológica, no espaço informal, o foco era o texto em si, a obra em sua amplitude, o que tomaria mais de um encontro.

Lembro muito bem de o primeiro encontro do grupo dos seletos que participei dar conta do complexo texto de Eudoro "Arte e escatologia" ${ }^{2}$. Esse conjunto de reflexões sobre uma filosofia da arte era texto programático para o qual e do qual convergiam e partiam proposições presentes em diversos momentos da trajetória eudoriana. Para nós, contudo, era tanto um misterioso objeto de culto quanto um impulso para o pensamento. Compreender e decifrar eram atos correlatos. Como éramos jovens, e não tínhamos o lastro cultural necessário para empreender um melhor diálogo com o texto, adotávamos uma leitura que mimetizava a estrutura dispersiva do texto: cada parágrafo, cada linha e muitas vezes alguns vocábulos eram indutores de devaneios racionais, de esboços de desdobramentos discursivos. Tal leitura intensiva era praticada nesses momentos por Ronaldes. A dinâmica do encontro era o seguir do texto, puxado pela primorosa condução do mestre. Assim, exibia-se uma estratégia performativa na qual a interação com o texto por parte do condutor da reunião se efetivava na construção de uma fala imediata, altamente bem elaborada que expandida algum tópico lido. A interpretação dada parecia surgir no momento de sua proferição.

Por exemplo, a primeira linha do texto “Arte e escatologia" assim rezava: "Definição é preceito que pode convir a um filosofia que se ensina; não, todavia, a um filosofar que se aprende ${ }^{\prime^{3}}$. Lida, a frase ecoava em nós. Depois Ronaldes passava a uma análise e amplificação da sentença, que em si mesma parecia como uma sabedoria, tão bem elaborada e concisa. No caso temos uma contraposição entre dois modos de se produzir conhecimento: um impli-
1. Sobre as ideias de Ronaldes de Mello e Souza, v. MOTA 1994

2. 0 texto é capítulo do livro de Eudoro Dioniso em Creta e outros ensaios (Duas CIdades,1973), pp. 165-182.

3. SOUZA 1973:165 
citamente ligado à práticas reprodutoras e outro a práticas emancipadoras. Tal contraposição era a base do modelo eudoriano, presente nos encontros com Ronaldes. Os grupos surgidos em tornos dessas figuras tutelares prescreviam uma série de procedimentos e posturas que visavam ao ideal de um sujeito ativo, crítico, conhecedor de muitas coisas e que se movimentava livremente nesse desejo de mais saber, rumo a uma excelência. Para alcançar essa meta ou estado, estes procedimentos estabeleciam uma relação irônica, acusatória e depreciativa daquilo que era considerado seu oposto. Havia a necessidade do inimigo para que o triunfo fosse atingido. Assim, no seio do grupo em maior ou menor medida se instalava uma cultura do melhor que se defrontaria com os hábitos do pior. Claramente, dentro dos espaços informais, os libelos rebaixadores do antagonista se manifestavam mais incisivamente. 0 prazer de

4. Entrei para o Mestrado de Teoria da Literatura da UnB em 1989 e conclui o curso, sob orientação de Ronaldes, em 1992. A dissertação intitulava -se A hermenêutica da imaginação em Adonias Filho. conhecer se aliava à satisfação prazeirosa da burla. Mas a condução fazia desses momentos irônicos não êxtases isolados, momentos desconectados de toda uma argumentação e práxis interpretativa. Identificar o limite dos outros era complementar ao se situar dentro do horizonte aberto pela experiência de ser um melhor leitor, de saber distinguir a relevância das ideias e das obras.

Dessa forma, os laços entre os membros da comunidade de aprendizagem não eram apenas intelectuais - eram existenciais. As mudanças nos modos de se trabalhar com textos e ideias eram incorporadas em palavras e ações. As demandas propostas e adotadas para se interagir com os livros eram transpostas para a vida de cada um. Esse momento de fusão do leitor com o homem projetava a etapa seguinte e depois desejada (e por alguns atingida) que era o de se chegar à autoria, de se passar de leitores de obras para criadores, seja como literatos, seja como transformadores de sua própria existência. Para jovens que se iniciavam naquela experiência, tal possibilidade era muito atrativa, determinava o que se fazer pelo resto da vida, que agora era sonhada e planejada. Lembro-me muito bem das dificuldades e dos ganhos presentes quando da elaboração dos primeiros textos, literários e ensaísticos. Eram produtos daquele grupo, os quais em nossa imaginação pensávamos estar nos inserindo na tradição afortunada, no cânone, no rol dos melhores.
Realizei meu mestrado como extensão desse grupo, dessa poética e política eudoriana subjacente à tutoria provocativa de Ronaldes. Nessa época as coisas começaram a encontrar um outro viés. Pois a emancipação visada pela didática irônica incluía um descolamento do membro em relação ao grupo. Minha dissertação apontava para isso: ao mesmo tempo que era um produto cuja feitura representava uma culminação das práticas e dos ideais defendidos na comunidade de aprendizagem, também se deslocava em outras direções, divergindo de interpretações do texto realizadas nas aulas e encontros.

Assim, temos na minha dissertação aquelas sentenças tipicamente eudorianas, uma dimensão filosofante que se conecta ao exame minucioso das fontes textuais e uma certa dose autoral, na expressão de um ensaísmo que coordena os requisitos da pesquisa com a qualidade da atividade escritural ${ }^{4}$. Enfim, o paradigma eudoriano de se aproximar filologia e filosofia se manifestava em mim na adoção de um estilo que conjugava abstração, expressão escrita e análise textual.

Na mesma época (em 1992), apresentei na Associação Brasileira de Literatura Comparada(Abralic) uma comunicação que procurava discorrer sobre aquilo que eu achava ser mais importante sobre Eudoro de Sousa. 0 texto " 0 logos do mito em Eudoro de Sousa" não fazia referência aos temas aqui tratados neste artigo: antes, era uma seleção de passagens de várias obras de Eudoro cuja coerência se dá em relação ao que seria pertinente à minha disssertação: fundamentar uma abordagem sobre a representação da finitude em obras literárias. 0 que me chamava mais atenção, fiel aos meus impulsos iniciais a Eudoro, era entender a atividade mitopoética, que, no caso, não se restringia ao impulso criativo presente nas obras dos escritores gregos. Dessa forma, tal atividade mitopoética bem caracterizada esclareceria meu próprio projeto artístico, como ser veria nos textos que publiquei em 1997 reunidos sobre o título de $A$ idade da Terra. Da leitura de Mitologia em 1985 à comunicação à Abralic em 1992 se estende um arco de amadurecimento no qual o fascínio imberbe se transmuta em texto conceitual. De 1992 a 1997, a abstração, os devaneios conceptuais se deixam aprisionar por poemas. 
Em 1995 iniciei minha carreira de docente na Universidade de Brasília, como professor de Teoria e História do Teatro, no Departamento de Artes Cênicas. Ainda um eudoriano em senso estrito, como exigência de então para jovens professores, propus e ministrei o curso de extensão "Mito e Filosofia dem Eudoro de Sousa.", como uma introdução ao seus livros e pensamento. 0 curso me deu a possibilidade de reler mais uma vez todo o material de Eudoro disponível, ao mesmo tempo que eu me relia, questionando-se sobre minha pertença aos modos daquela comunidade de aprendizagem, que, neste momento, havia se esfacelado com a ida de Ronaldes para o Rio de Janeiro.

Assim, no momento em que começava a assumir um papel de líder de processos de aprendizagem, eu me via na situação de rever o que levaria adiante em relação aos modelos de transmissão e transformação de conhecimento por mim experimentados.

Frente a este novo e intenso contato com Eudoro, não mais vinculad a minha proto-comunidade, além do curso de extensão, preparei para e editora da UnB uma nova edição de Filosofia Grega e elaborei materiais para conferências sobre Eudoro.

A publicação da nova edição não vingou. $E$ a frustração foi grande: na verdade estava existencialmente muito vinculado ao Ronaldes e a Eudoro. Produzir aquela edição era como espécie de retribuição, de gratidão, ao mesmo tempo que marca de fim de processo. Essa interrompida forma de se dizer adeus hoje vejo de uma maneira positiva: fui seguir meu caminho, mantendo algumas coisas que aprendi com meus mestres, mas, contudo, direcionei minhas preocupações e realizações para novos objetos, novos acontecimentos e práticas apenas parcialmente tangidos na esfera eudoriana(teatro, criação literária). Se tive que me inventar existencialmente para empreender o que hoje sou capaz, integrando textos e audiovisualidade, foi porque tive minha primeira experiência com o pitagorismo/ socratismo daqueles textos e daquela comunidade.

Antes, para que não permaneça um tom de fracasso no ar, em 2011, a reedição de Filosofia Grega foi retomada. A reedição anotada que eu fizera se perdeu. Para tanto, entrei em contato com a viúva do saudoso Fernando Basto, guardião da herança eudoriana. Em contato com Zuzu Bastos fuçamos o baú de Fernando Bastos e, para minha alegria, os materiais do Centro de Estudos Clássicos, muitos deles eram lendários entre nós, de fato existem, como o fabuloso e mítico curso sobre as catábases, outro sobre fontes de estudos da tragédia grega, e outro ainda sobre língua grega, fora outros textos soltos. Há muito material para livros e pesquisas. Como o baú de seu conterrâneo Fernando Pessoa, obras e obras continuam a jorrar. Para felicidade de todos os que sentem alcançados e atingidos pelo impulso mitopoético da Antiguidade, o qual se manifesta das mais variadas formas em cada um de nós.

Para tanto, enquanto a nova edição de Filosofia Grega é publicada, disponibilizo os textos que produzi em torno de Eudoro de Souza. Em ordem temos 1 - 0 Logos do Mito em Eudoro de Sousa, comunicação para a Abralic, de 1992; 2 - Cronotopia mitopoética em História e Mito de Eudoro de Sousa, texto suplementar para o curso sobre Eudoro de Sousa, UnB 1995; e 3 - Notas para o jogo em Heráclito, também texto para o curso sobre Eudoro de Sousa, UnB, 1995. 4 - Notas para Prefácio a uma possivel nova edição de Filosofia Grega e Sempre o mesmo acerca do mesmo.

Nestes textos pode-se acompanhar as dinâmicas da recepção da obra de Eudoro em momentos que se definem em função da proximidade ou não da comunidade intelectual como contexto para elaboração e circulação de produções. Assim, o primeiro texto, que busca apresentar Eudoro para outras audiências que a da comunidade, guarda ainda tanto um caráter crítpico, hermético, em função de posturas e dogmas acatados e tidos como norma-guia. Se o conhecimento produzido era voltado para o grupo e contra os outros, o resultado disso é um exercício de aproximação ao tótem. Tal inflexão ainda se vê no texto 2, no que se refere à exploração do vocabulário e de modos de construir palavras, mas, diferentemente do texto 2 , a sintaxe não é tão elíptica e descontínua, demonstrando um maior direcionamento para a inteligibilidade do que se expressa. Já o texto 3, mesmo com Eudoro abrindo e fechando as pontas da cadeia, há um espaço para um deslocamento tanto temático quanto linguístico do modelo adotado. Eudoro se converte 
em uma citação e não em fonte única. Antes eram suas palavras o foco, a repetição delas como um mantra. Agora, procura-se estudá-lo, e não mais apenas imitá-lo. No texto 4, enfim, passados anos mais de 25 anos de meu primeiro contato com Eudoro, note-se que tanto o estilo de escrita quando o conteúdo apresentado não mais se pauta pela paráfrase. Nesse sentido, creio que os devaneios alçados na proto-comunidade alcançaram seu alvo: a autonomia, a liberdade do intérprete.

De qualquer forma, a compreensão de como os textos foram elaborados, o esclarecimento de seu contexto não neutraliza o que eles são: negociações com suas fontes, com os modos de se selecionar e priorizar certas táticas expressivas em detrimento de outras. Mas, no fim, os textos valem por aquilo que eles são em si mesmo, nem puramente ecos, nem completamente autarquias.

\section{Texto I}

0 Logos do Mito em Eudoro de Sousa ${ }^{5}$

5. Comunicação apresentada ao $3^{\circ}$.Congresso Abralic,São Paulo, 1992.

6. As abreviaturas relativas à obra de Eudoro de Sousa são as seguintes: (MIT) - Mitologia Editora da Universidade de Brasília, 1980; História e Mito (HM), Editora da Universidade de Brasília, 1981; (HC) Horizonte e Complemetaridade, São Paulo, Duas Cidades, 1975; (SMAM) Sempre o Mesmo acerca de Mesmo, Editora da Universidade de Brasília, 1978; (DC) Dioniso em Creta e Outros Ensaios, São Paulo, Duas Cidades 1973; (BA) As Bacantes, de Eurípides, São Paulo, Duas Cidades, 1974. comunicação apresentada ao $3^{\circ}$. Congresso Abralic,São Paulo, 1992 As abreviaturas relativas à obra de Eudoro de Sousa são as seguintes: (MIT) - Mitologia Editora da Universidade de Brasília, 1980; História e Mito (HM), Editora da Universidade de Brasília, 1981; (HC) Horizonte e Complemetaridade, São Paulo, Duas Cidades, 1975; (SMAM) Sempre o Mesmo acerca de Mesmo, Editora da Universidade de Brasília, 1978; (DC) Dioniso em Creta e Outros Ensaios, São Paulo, Duas Cidades 1973; (BA) As Bacantes, de Eurípides, São Paulo, Duas Cidades, 1974

$$
\begin{array}{r}
0 \text { que no mundo acontece são as malhas } \\
\text { que o deus tece (MIT, 150) }
\end{array}
$$

As linhas diretrizes do pensamento de Eudoro de Souza se encontram num texto programático apresentado no III Congresso Nacional de Filosofia, em 1959, que se intitula "Teísmo, Cosmobiologia e Princípio de Complementaridade". Reorientando o célebre conceito da física contemporânea em função do questionamento da tradição de ideias ocidental, Eudoro busca romper com a oficiosidade de um pensar absolutista e totalitário, excluidor das diferenças, em prol do resgate e reabilitação do componente mítico de nossa cultura. Ou seja, a partir de uma releitura da tradição ocidental européia, tendo por base a revisão de suas facetas mítico-metafísicos, Eudoro de Sousa progressivamente repõe o mítico, procedendo, já no fim deste processo, à radicalização do simbólico, postulando-o como pré-determinante na constituição dos sentidos e significações em que a compreensão humana se debate.

Várias questões, em razão disto, aparecem interligadas: a fenomenologia da consciência re- ligiosa como aporte para codificações filo-míticas complementares da realidade; a origem da poesia na crise religiosa grega; a motivação hermenêutica das representações míticas; e, finalmente, elementos para uma teoria dramática do conhecimento, a ser realizado por uma anábase meta-histórica. Contudo, o fio coesivo-explicativo se encontra no logos do mito.

Será a mitologia apenas biografia de deuses? Será ela apenas um conjunto de narrativas a respeito dos sucessos e insucessos das relações entre deuses, homes e mundo no que estes sucessos e insucessos infundem de mais diretamente? De que nos fala o mito, se é que ele se impõe a algo definir? 0 que se representa, o que se pensa na mitologia? Terá o mito o seu logos, não no sentido lógico-discursivo, mas como mediação e meditação do modo de ser existenciário do homem?

A visão normatizadora do mito tenta apreendê-lo dentro dos percursos dominantes da tradição filosófica ocidental, por meio da fórmula "do mito para o logos". 0 percurso positivista da humanidade é o da negação de sua componente mitológica.

Este conflito entre duas ordens de mundo iniciou-se, segundo Eudoro, na Grécia. Ao refutar aspectos pré-helênicos de sua cultura, a Grécia preparou a metafísica e a formalização de um saber indisposto à própria experiência de pensar, um saber desconectado da existência, um conhecimento sem ritual e sem culto, aplicável em qualquer situação nenhuma. A codificacão dos eventos passados, dos eventos primordiais, é feita para descontextualizar uma interrogação sobre as origens. Assim, a mitologia, esta meta coleção de narrativas, torna-se “eutanásia do mito pré-helênico (DC, 30)".

Ponto fundamental para esta mudança de mentalidade se encontra na nova concepção da morte. À unidade religiosa da mediterrânea oriental, cultuando a morte de um deus que dava origem aos homens e ao mundo, provando a sobredeterminação da finitude como horizonte possibilitador do ser, contrapõe-se o monologismo burocrático-administrativo dos limites. 0 que importa é aplainar a diferença e a descontinuidade que a finitude revigora. Esta é a crise da consciência religiosa grega (DC, 75-91), na qual se avista o distanciamento de um pensar comprometido com os fundamentos existen- 
cais finitos da compreensão humana. Tal reversão e julgamento da morte operado pela reforma homérica desentendem "a existência dos deuses antes que a filosofia thes alterasse o modo de existirem: uma vida condicionada pela Morte (DC, 158-159)".

Ora, desconsiderando os deuses em sua agonia fundante e a morte como possibilidade, como criação, a simples biografia dos deuses ignora que o drama ritual mítico encena a morte destes que, “morrendo, se transformam nas coisas vivas que há no mundo. (...) Em verdade os deuses não criaram o mundo; transformaram-se no mundo (...), intricados fios de uma teogonia e de uma cosmologia (...) cujo argumento poderia ser formulado nestes termos: como vive o mundo a morte dos deuses, sem que os deuses deixem a viver no mundo (DC, 162-163)".

0 mito não é discurso compatível com a despotenciação do aspecto tanático efetivo da existência. Antes, articula a sensibilidade humana que tira seu vigor da morte enquanto possibilidade de sentido. Vida e morte são complementares.

A vocação ao contraditório, para unir momentos que, no horizonte comum da existência humana, estão isolados, já na etimologia mesma da palavra 'mito' transparece: "entre mito (poesia) e mistério (religião) se interpõe a diversa quantidade de uma vogal...0 verbo que corresponde ao substantivo mythos é mythéomai, que significa "falar", "dizer", e ambos os vocábulos provêm de uma raiz que contém um " $\mathrm{y}$ " breve; o verbo que corresponde ao substantivo mystérion é myein ou myeisthai, com o sentido de "fechar"(olhos, boca, ferimentos), em que a raiz my- se escreve com " $y$ " longo, e figura, por exemplo, no latim mutus e no sânscrito mukas, ambos os termos com o significado de "mudo", "silente". Por conseguinte, a oposição da quantidade vocálica parece somar-se à oposição semântica entre a palavra e o silêncio, o silêncio e a palavra" (DC, 177).

Com isso, o mítico situa-se dinamicamemte no intervalo limite-liminar da expressão, no qual verbalidade e silêncio se implicam mutuamente. A palavra no mito é um discurso que não se totaliza na expressão. Não existe a ruptura entre processo de representação e representado. 0 dito sempre é acompanhado de um não-dito, de uma tematização de sua possibilidade de sentido. A fala mítica não está circunscrita à localidade de seus elementos. Não se trata de apresentar um referente decomposto de destituído de sua instância de efetivação. 0 percurso temporal do simbólico é o transcurso da simultaneidade entre a origem e o originado, demonstrando que compreensão de um processo de sentido se encontra presente em todas as etapas de sua elaboração. 0 sentido a constituir está no tempo de sua constituição para que se observe a indissociabilidade entre estrutura da criatividade e a tematização de um saber. Sem um horizonte de possibilitação, o discurso é uma decorrência de feitos formais e recorremtes em uma generalização.

Com isto, no mito não temos categorias, mas sim tautegoria (DC, 139), por meio da qual “o que através da poesia nos aparece como sendo mais do qe parece é a própria originalidade do que aparece $(\mathrm{HC}$, 171)". Este movimento de ir do mesmo ao mesmo, passando pelo outro, este circuito ontogenético do tempo, é a operacionalização mesma da finitude que o mito faz, fiel ao seu estatuto dramático de encenar as faculdades humanas em performance. 0 mito toma sua substância da mesma matéria que representa. Explicita-se a tautegoria mítica com as catábases, teogonias e metamorfoses.

$\mathrm{Na}$ metamorfose ocorre a alteridade por meio da compreensão dos limites. Só há abertura pela integratividade da finitude. "A metamoforse é alteração, passagem do mesmo ao outro, e o limitar do outro é a morte (...) Momento decisivo da metamorfose é esta morte latente na vida (MIT, $61)^{\prime \prime}$. A metamorfose é a verticalidade que explora a dialética da identidade e da diferença. 0 que difere não é resíduo de um modelo. Trata-se do diferencial da própria diferença, em que, na raiz de sua complementaridade, finitude radical e nada dialogam. 0 que interessa na metamorfose não é simplesmente a alteração da forma, a mudança da forma, a mudança dos estados, mas consciência da unidade na diversidade. Antes da forma, a tensão nos limites e limiares de um processo de formação, As catábases remontam à ultrapassagem do horizonte comum da existência, para que se alcance a circularidade inerente ao tempo em que um sentido se aprofunda e se diversifica. 
Como ritual de iniciação, a catábase é uma situação liminar, por meio da qual os limites são problematizados e compreendidos em seus dividendos hermenêuticos. Mas é na discussão em torno da cosmogonia que a tautegoria mítica melhor se divisa.

Qual é o mundo do mito? Se no mito narra-se uma cosmogonia, uma antropogonia e uma teogonia, seu discorrer é uma pergunta pelas origens que é origem de todo o perguntar (MIT, 48). A simbologia do primordial se ajusta à representação da primordialidade das capacidades registradas na compreensão. Questionando o dado realístico ou o solipsismo individualista, sujeito e objeto são ultrapassados para que se coloque a dramaticidade de um homem e de um mundo unidos por um nexo não imediato, ausente, mas que sustenta todas as correlações. Nesta religação do originado com suas origens, os originados reverberam uma genescatologia; e este item é um critério que apresenta o que é a verdadeira mitologia: "excluir do âmbito da mitologia o mito que não se situe entre dois extremos, num dos quais reside tudo o que respeita a uma teo-antropo-cosmogonia e, no outro, uma escatologia. Porém, numa perspectiva de complementaridade, não se pode excluir a hipótese de que tais extremos não coincidem: que 'o de onde viemos' não seja o 'para onde vamos' (SMAN, 7)".

0 mundo do mito é, pois, o da intersecção entre relações de sentido que configuram a interdependência da originação com a telecologia do originado. 0 mundo como corpo vivo de um deus morto é cifra da sobredeterninação finita do virtual. Assim, cosmofania é teocriptia, sendo que o "mito não nos relata o aparecimento dos deuses no mundo, mas sim, o seu desaparecer no aparecimento do mundo que eles só acenaram, enquanto acenantes mensageiros da Divinidade (MIT, 150)". Um deus que morre para que o mundo nasça, faz o percurso inverso do que originou. Registra que a finitude radical é criadora, indica que só possibilita o que se possibilita, o que se finitiza.

Desse modo apresentado, o mito reabilita-se. Constitui-se como "a priori de todos os a priori da sensitividade, da intelegibilidade e dos pré-fixados condutos da ação humana, em qualquer cultura bem caracterizada (SMAN, 6)". A reversibilidade ontológica do mesmo e do outro como projeções cronotópicas da sensibilidade dramatiza-se em um discurso imaginativo suspendido, interrompido nas raízes de suas possibilidades, na catástrofe simbólica em que homem e mundo, co-jogados, dimensionam-se na ausência total ou presença dependente a potência originária e originante ${ }^{7}$.

$\mathrm{Na}$ estrutura arquetípica da compreensão humana, finitude e nada se coordenam pela coordenam pela inexauribilidade do discurso mítico. Fluídas e translúcidas, as criaturas míticas difundem a entreabertura máxima de sua mutabilidade: mais real quando mais ficcional. 0s limites aprofundamse, ampliando suas potencialidades. Excessivos, plasmáveis, comunicam que “há uma parte de nós, a melhor parte de nós, tão secreta, tão absoluta, tão excessiva como a Suprema Excessividade, como o mais Selado Segredo, como o mais Separado Absoluto. Uma parte de nós que continua habitando na Fulguração ofuscante - possuída por Ela, pertencendo a Ela, sendo como Ela: é a nossa irredutível subjetividade, aquela que nunca será objeto, por que é condição de toda objetividade (SMAN, 28)".

Reabilitando-se o mito, reabilita-se o próprio homem. A reversão dos acentos valorativos que imobilizaram o livre exercício das potencialidades da compreensão sedimenta-se na primazia do mito como fundamento da história. A falida tradição onto-teológica ocidental é contextualizada em função do vigor do simbólico. As dualidades são justapostas em sua hierarquia radical. “Um kósmos é um khaós, um excesso que por instantes é detido no ímpeto de a si próprio ultrapassar" e o deter, a disciplina, ordem não se exercem contra o excesso, mas são suscitadas pelo mesmo excesso, "como se o excessivo de si próprio o solicitasse a única força contrário de o mostrar e o demonstrar como excessividade (BA, 123)".

Longe de se confundir com um irracionalismo ou racionalismo, a redenção pelo mítico revela um rigor em sua lógica onírica para enfatizar os possiveis, os virtuais como limites e horizonte da estrutura pressupositiva da compreensão. Só condicionando pela abertura da expressão é que se ascende à experiência de pensar em sua autenticidade e diferenciação. Deste modo, “o cosmo está 
para o Caos como o logos está para o mito, como o produzido está para o producente. 0 lógico e 0 cósmico vinculam-se um ao outro, como um a outro se vinculam o mítico e o caótico, e os dois vínculos se identificam no que une o producente com o produzido (HM,65)". 0 logos do mito, o que se pensa no simbólico, é a disponibilidade da compreensão no processo efetivo de sua factível realização.

Homens e deuses se encontram neste mundo. Descentrado e extático, o homem pode abrir-se para este encontro e este diálogo. É o tema da soteriologia eudoriana: "Não cremos, todavia, que Deus esteja morto; nem sequer os deuses... Esperam 0 mais íntimo de nós, a hora de começar representando conosco o papel que lhes está designado no drama do imenso tédio que a humanidade acabará por sentir de si mesma (apud Bastos, 1990, VI)". Nesta soteriologia, uma anábase meta-histórica facultará a redenção do homem por meio do diálogo com a sua alteridade, num encontro com o outro inerente a si mesmo (MIT, 158). A atividade mitopoética assim compreendida ensina o homem a assumir a facticidade e abertura de sua constituição.

\section{Texto II}

Cronotopia mitopoética em História e Mito de Eudoro de Sousa

"A história anda à mercê do mito" (HM, 18 $\left.{ }^{8}\right)$

A obra História e Mito (HM) pode ser considerada como o testamento do percurso intelectual e existencial do pensador Eudoro de Sousa. Ao mesmo tempo em que retoma proposições dos livros anteriores, aprofundando-as, deixa ao leitor uma série de indagações a respeito do mito e de sua reavaliação.

Retomadas são as seguintes questões: a problemática da religatio entre deus e homem por meio do drama ritual que, culturalmente, os institui; crítica integrativa do monologismo ocidental que se expressa, em contradição com sua vocação positivista, como o mito do homem metafísica do centramento e unificação do sentido; revalorização do mito iluminada através de sua poética; hermenêutica do mítico que, ao apresentar seus constituintes, demonstra que os tais são inerentes à compreensão mesma, em sua efetividade. Por este último item, as razões do mito fornecem os elementos para uma soteriologia que redimirá o homem de seu percurso totalitário ${ }^{9}$.

0 conjuntivo "e" do título elabora uma disjunção interpretativa que o prosseguir do texto executará. "História" e "mito" comparecem em uma oposição que será resolvida em um plano superior, o do símbolo, em que se avistarão as especificidades dos pólos. A oficiosa preponderância da história será negada em prol da primordialidade do mito. Trata-se da revelação da verdade por meio do ritmo alethopoiético em que se fundamenta a escritura e o pensamento de Eudoro de Sousa ${ }^{10}$.

Inicialmente, a exegese do mito orientará esta revolução copernicana: contrariando os modelos referenciais e representativos dos discursos impressos no circuito sujeito-objeto, o mito radica na fusão e indistinção dos opostos (HM, 4), por meio da qual se experimenta a lonjura indimensionável dimensão do espaço, que não é espaço, e sim um além-horizonte e o outrora - indimensionável dimensão do tempo, que já não é tempo, mas um além-horizonte (HM, 3-4). Nesta ucronia do transobjetivo, homem e mundo encontram um destino de excessividade, no qual a inexauribilidade opera.

A reversa e diversa cronotopia da lonjura e do outrora rompe com a indisponibilidade do imediato. Requer-se uma recondução à modalidade efetiva em que se desdobra a existência humana. Elabora-se um “pensar o antes, em que selados se encontram os destinos do que venha a ser mundo e do dizermos nós o que o mundo seja. 0 "antes" encerra possibilidades de mundo, realizadas ou irrealizadas e a nossa existência parece estar tão presa a umas quanto a outros. (...) Pensar o 'antes' é pensamento de metamorfose, de vida que decorra de mudança em mudança de formas destinais, de reabertura em reabertura, para realização de possíveis sempre outros (HM, 66)".

Para este passo, subverte-se o eixo normal do tempo, para que se concretize este ser em trânsito (HM, 10): “Tempo concreto não é linha que corre para trás e para a frente de qualquer de seus pontos: é campo de polaridades. (...) Não se imporia a necessidade de substituir a concepção de um eixo

\author{
8. Cito História e Mito, seguindo \\ sua edição pela Editora da \\ UnB,1981. \\ 9. Quanto à soteriologia \\ eudoriana, v. Tese de \\ doutoramento de Fernando Bastos, \\ intitulada Eudoro de Sousa e a \\ complementariedade do horizonte, \\ PUC, 1980. \\ 10. Quanto à Alethopoiéses, v. \\ capítulo "Alethopoiéses" da Tese \\ de doutoramento de Ronaldes \\ de Melo e Souza, intitulada A \\ hermenêutica da concriatividade, \\ UFRJ, 1988.
}


cronológico linear e, contínuo, em que se assinalam pontos intercambiáveis de passado, presente e futuro por "futuro por um campo de polaridades? (...). Pressupor a estrutura da realidade histórica, equivale a ter concebido a diferenciada e heterogênea textura do tempo(HM, 11)".

Com isto, conjugam-se a destinação transformativa do homem com a consecução diversificante da história. História e homem comparecem em sua originária forma de expressão porque ambos irrompem da mesma fonte o mito, que funda o ser de tudo o que é ou existe. 0 circuito genescatólogico do mito configura o percurso do homem, fazendo com que os planos da realidade se coordenem em função de seu projeto originante.

Duas modalidades epocais se intercruzam. A presença do presente e a presença do passado. A primeira é a da ordem do mito do homem que, como ser da recusa, nega as diferenças em prol da modelização de sua experiência. Contudo, cada epocalidade tem seus referentes cronotópicos, de acordo com o sentido que a funda. À generalidade de seu poder contrapõe-se a faticidade do poder ser. A presença do presente, centro convergente da conservação de um estado histórico, só persiste em durar porque se aliena do contexto de sua produção. 0 privilégio de sua posição só se faculta na particularidade que a si mesmo autorefere.

É que a história não quer saber do mito, a presença do presente desdenha da presença do passado. Como época das épocas, esta, em sua ausência fundamente, resguarda resguardando-se (HM, 72). A sua verdade não se identifica com 0 exclusivismo de um pensar desconectado de suas origens. A presença do passado, fonte «das excedências virtuais do presente e do passado»(HM, 86), desenvolve-se em um regime noturno da consciência» (HM, 57), por meio do qual rediscutem-se os mecanismos referenciadores e doares do real. Contrarconformativa e unilateral da substância, da causualidade e da necessidade, transmuta-se 0 imediato no mediato. 0 que importa é a estrutura efetivadora do acontecer de sentido. Nega-se a esfera elementar de um sistema produtivo, repondo a não localidade de sua configuração tensiva. Assim age o mito: perpassa o atual, transpassando o habitual.
Perpetua-se através de sua cronotopia às avessas. A teleologia mítica, ao invés de encerrar sua destinação, suprimindo o vigor de seu projeto, reenvia constantemente para seu processo. É processo de processo, é dual e duplo posto que dimensiona-se na indistinção dos contrários como forma de conciliar a simultaneidade de sua genescatologia.

0 mito assume, então, a primordialidade que o define. É discurso das origens, pois discorre acerca de como se desdobram, efetivamente, as capacidades humanas. Ao interpenetrar as arquiacenações de onde viemos e para onde vamos o mito surpreende a coalescência originária em que se divisam as possibilidades mistéricas da disponibilidade (HM, 84-88). Em sua reversibilidade do mutuamente implicado, suspendem-se as constâncias formais no fascínio do transformativo. A primordialidade do mítico fenomenaliza-se através da plasticidade que a fundamenta. É “o mítico que dá origem ao lógico; não o que the dá início, mas o que o sustenta, do início ao término. Será o logos um subproduto do mítico, como um cosmo é subproduto do Caos? (...) 0 cosmo está para o Caos como o logos está para 0 mito, como o produzido para o producente. 0 lógico e o cósmico vinculam-se um ao outro, como um ao outro se vinculam o mítico e o caótico, e os dois vínculos se identificam no que une o producente com o produzido(HM, 64)".

A presença do passado é a abertura às disponibilidades do ser em processo, do ser que ilumina suas possibilidades de expressão. É como se o que existe, persistisse na tensão de sua entreabertura, encenando a virtualidade de sua aparição. 0 que aparece sendo mais do que parece mais indissoluvelmente relacionado com seu evento - eis o mito.

A chave para a revalorização do mito se averigua na compreensão do aspecto tanático da existência. Ordinariamente, a morte é despotenciada, entendida como mero resíduo insignificante de uma movimentação já pré-dada. 0 fim apenas confirma uma indisponibilidade cursada. 0 término de antemão foi traçado (HM, 65). Conservem-se as relações de sentido no espelhismo condicionado à reverberação do já infirmado por um modelo articulador. Interrompe-se a processualidade do conhecimento, visualizando-se a aporia das gene- 
ralidades ou particularidades que consagram um saber na atualidade de seu absolutismo e espacial a temporalidade. A morte é o fim a vida, na medida em que a emoldura como reticente acréscimo a algo que já perdeu seu vigor.

Mas no mito, ao contrário a morte é fundadora, o limite é incorporado enquanto potencial criativo. A morte é metamórfica (HM, 92). Quanto mais se finitiza, mais se cosmiciza. A presença do passado se faz atuante na intermediação de seus efeitos. Com isto, fim e início não são demarcações de sua efetividade. A recursividade mítica atrela-se à não exaustão do que origina. 0 horizonte do mito é a reposição de suas possibilidades.

A presença do Presente é um extático acontecer da presença do passado. A sua máxima dominação e epifania não se resolve em luz para consigo mesma, mas como iluminação e descortinamento do que a sustenta. 0 lascinante fascínio do que ora imobiliza apenas valida-se no silêncio das convulsões prementes do caótico.

"História" e "mito" não são rivais. Ao se superar a miopia interpretativa que confunde a elementaridade fenomenológica do que acontece com a estrutura de seu acontecer, revertem-se as valorizações tradicionais na celebração de uma expressão que recupera o sagrado a excessividade divina que radicaliza o percurso existencial humano. A qualquer momento a história se dobrará ao mito, redimindo-se de seu percurso denegador. Os discursos encontrarão a dignidade de seu entusiasmo e dizer não será mais nomear as coisas, mais trazê-las à existência. Não haverá mais caminho, mas sim um complexo satyricon: cronotopia do sem-tempo e espaço no hiperbólico referencial sem referência, a não ser o próprio diferencial da diferença - descentramento, mitopoética.

\section{Texto 3}

NOTAS PARA O JOGO EM HERÁCLITO

Quem ascende ao trajeto intelectual de Eudoro de Sousa a partir da pergunta que o norteia só pode responder afirmativamente ao que o título interroga. Uma História da razão é o que se revela nas diversas tentativas de sempre acerca do mesmo compreender o chamado milagre grego por outro viés historiográfico que o circuito do Mito ao Logos.

Contemporâneo dos processos que desde a fenomenologia demonstraram a faticidade do logos, inserindo-o no contexto de sua produção, Eudoro de Sousa persegue na Grécia o tempo e o espaço privilegiados nos quais a racionalidade não era a absoluta veridicção de si mesma. A obra eudoriana se consagra à atividade de reflexão que se pauta pela integratividade, conceito hermenêutico (GADAMER 1987 :261-262) que postula a finitização radical de toda construção de sentido que, não sendo absoluta, reivindica a descontinuidade, o diagrama de sua experiência expressiva. Tal História da razão não é contra a razão, mas contra qualquer postulado antimimético.

Descrevendo as formas de religiosidade pré-helênicas em seu corte transversal da cultura grega (Dioniso em Creta e outros ensaios, Sempre o mesmo acerca do mesmo), procurando contextualizar a experiência dramática e sua lógica dionisíaca, para além do racionalismo estreito iluminista e pós-iluminista dos filósofos da chamada Cultura Clássica (Uma leitura de Antígona, traduções de As bacantes, de Eurípides e de Poética, de Aristóteles), reinterpretando a História da Filosofia pela interpenetração dos projetos dos pensadores chamados pré-socráticos e dos filósofos Platão e Aristóteles (Horizonte e complementaridade e Filosofia Grega) e transformando este transcurso em uma Poética da História (Mitologia I e Mitologia II), Eudoro de Sousa existencializa o Logos, mostrando que a Grécia nos legou uma racionalidade que quer pensar o que não se reduz ao pensamento, ser não é igual a pensar.

Na Grécia, então, transparece uma crítica à razão, antes mesmo do Logos generalista. A Filosofia Grega, frente ao mito, legou-nos a interpretabilidade, nosso modo de ser interpretativo, dialogante, sempre limitado à atividade aproximativa que é fiel à irredutibilidade da imagem à seu comentário apenas. Os gregos, pensando contra ou a favor do mito, pensaram com o mito, pensaram figurativamente ou tomaram da figura seu referente e referendo (VEYNE 1989). Temos a condição mimética dos discursos. Não é possível o puramente conceptual. 0 horizonte figurativo abarca a demonstração gnesiológica. A 
mediação representativa é a condição da discursividade. Não há realidade sem representação. A estrutura pressupositiva do conhecimento fundamenta-se em seu suporte mimético. É para a Mímesis, para a representação da realidade que a filosofia aponta os caminhos do Ocidente.

E Heráclito estava lá, no começo e no fim desse processo.

As únicas imagens ( e as últimas!) que restaram de Eudoro de Sousa são as de um vídeo amador realizado por Reginaldo Contijo e Luis Fernando intitulado 'Videoeudoro'. Nele Eudoro, no final de sua vida, ofegante e cansado, em sua casa, comenta os fragmentos de Heráclito. A obsessão por Heráclito é proporcional à ira contra as interpretações apressadas que não compreendem a mimética racional que está em jogo, no jogo do logos. "Ele nunca disse tudo flui, tudo corre. Só a água corre. 0 rio continua o mesmo. 0 movimento da matéria não é problema de Heráclito. Não há dialética em Heráclito. Todo é um. 0 logos nos diz sobre a lei do universo. Mesmo e outro", braveja Eudoro de Sousa.

Esses comentários se apoiam na reflexão sobre o fragmento 12, aqui reproduzido, assim como os demais neste ensaio segundo tradução de Eudoro de Sousa em Filosofia grega: “Outras e outra águas correm para quem desce aos mesmos rios" Heráclito diz. $\mathrm{Na}$ leitura do texto, por uma ilusão referencial, ou um miopia interpretativa, pode-se confundir o representado com a representação. A forma proverbial-oracular de Heráclito exige que se correlacione o conteúdo proferido com sua configuração. Esta modalização da realidade estabelece uma estrutura correlativa que não é uma proposição. 0 referente da coisa é seu contexto de produção. Eis o fundamento da atividade mimética: frente à limitação do processo representacional (infinitude da realidade, atualidade finita da expressão), cada figuração é a dramatização de sua possibilidade mesma de expressão. Ironicamente, quem persegue as águas, perde o rio que em relação as águas permanece. 0 simulacro ideacional panta rhei permissivamente não leva em conta esta diversa referencialidade que o fragmento desenvolve. A leitura guiada pela atomização dos conteúdos resolve a tensão figurativa por meio da generalidade coercitiva da representação reduzida ao senso comum.
0 fragmento 91 , “Não se pode descer duas vezes no mesmo rio.. aflui e reflui... avança e retrocede...", é uma variação desta mesma estrutura que podemos denominar agonal na qual as partes interagem na distribuição de um ritmo de representação que se torna sua referência. A atividade mimética de Heráclito consiste em, a partir de flagrantes do cotidiano, promover um saber que desautomatiza os percebidos pela reposição de seu medium possibilitador dos eventos, correlacionando referência com orientação.

Continuando, no mesmo vídeo, a estrutura agonal de Heráclito é perspectivada pelo comentário de outros fragmentos. 0 fragmento 30 : “Este Kosmos [ que é o mesmo para todos], nem deus nem homem algum o fez; sempre foi e será um fogo continuamente vivo que se alumia por medida e por media se apaga", é interpretado por Eudoro de Sousa em função dos fragmentos 31 "Viragens do fogo: primeiro, o mar; e do mar metade terra e metade turbilhão ígneo- [terra] derrama-se se, qual mar à medida tal, qual era antes que este se tornasse em terra" e 36 "morte das almas; tornarem água; morte da água: volver-se em terra. Mas da terra (re)nasce água; e da água, alma".

Os três fragmentos introduzem a questão das viragens do fogo, tropai. 0 desvelamento da mímesis como forma de constituição de sentido homóloga à constituição da realidade em Heráclito obriga-o a tratar das viragens. Se no cotidiano nos deparamos com situações que, pelo reverso da expectativa, demonstram a limitação de nosso horizonte compreensivo, a representação desta limitação é a estrutura agonal dos acontecimentos, pela inserção do observador na realidade com a qual se depara. 0 que é a diversidade do real senão aplicação deste mesmo princípio norteador?

0 finito observador, sempre antecipando os eventos pela reposição do que conhece, vai confrontando a mudança dos eventos com a perpetuidade do mundo. A descontinuidade dos acontecimento só é percebida pela continuidade da realidade. A própria mudança é a construção da permanência. 0 revezamento dos presentes nos dá uma memória. $\mathrm{A}$ diferença é a compreensão desta identidade essencial de tudo que é ou existe. As viragens do fogo nos 
dizem que o fogo continua sendo fogo independente do fato de a água passar a existir. A mímesis de Heráclito é a dramatização de um logos posicional que doa a razão da transformação como inteligibilidade dos acontecimentos de sentido. 0 profundo logos da alma é extensivo da contextura variacional da realidade ( Conf. fr. 45 "Os confins da alma não acharias, nem que percorresses todos os caminhos; tão profundo logos ela tem."). Mas a profundeza e a variação não são abstratas. Heráclito finitiza o ato diferenciador pela reposição da precedência de um contexto produtivo. A multiplicidade, o vário são factíveis. 0 logos em Heráclito é a experiência dessa circunscrição que a mímesis dramatiza.

As viragens, a dinâmica transformacional da realidade encontram sua veredicção como compreensão deste logos. A metaforização da representação que as viragens nos facultam atualizam a excedência que o fogo aduz, como se vê no fr. 76: "Vive o fogo a morte da terra; e o ar, a morte do fogo, a água vive a morte do ar; e a terra, a da água."

0 que é, existe como acontecimento de uma diferenciação que guarda desta diferenciação a memória de sua faticidade.

É para o logos, como se vê no fr. 1, que a investigação de Heráclito nos conduz. A estrutura figurativa dos fragmentos é um pensamento sobre constituição de sentido dos eventos. Eudoro de Sousa passou a vida inteira na obsessiva e reiterativa meditação sobre estes fragmentos, como ele afirma no vídeo. Via nesses quase textos a codificação de uma historicidade que nos apela. "Ele nunca disse " tudo flui', me escutem, ouçam-me. Ele nunca disse isso." ainda ressoa.

Os fragmentos de Heráclito são um roteiro da compreensão da mímesis, em virtude de eles mesmos se representarem como mímesis. Não é à toa que Nietzsche compreendeu nessa forma dialogal de escritura, que contracena com o que expressa 0 fundamento da poética do drama (NIETZSCHE, 1995) - Platão, em A República, e Aristóteles, principalmente na Poética, também vão se ocupar da mímesis. A historicidade da filosofia passa pela reflexão sobre a representação. Eudoro dedicou em 1978 um curso sobre o fundamento mimético da filosofia(Filosofia Grega). Logos e mitos não se opõem, como se pen- sa, nem também se sobrepõe como se quer... A prefiguração da realidade, atividade da mímesis, é a destinação da filosofia e do 0cidente.

Filosofia grega era mais que um curso. Tratava-se de uma discussão orientada de textos fundamentais a respeito da especulação grega a respeito da mímesis, da representação da realidade, desde Homero até Aristóteles, textos todos traduzidos por Eudoro de Sousa. Uma descrição da estrutura do livro que recolhe o curso nos dá o contexto desta especulação .

Filosofia grega está dividido em quatro partes. A primeira recolhe fragmentos e relatos míticos presentes, principalmente nas obras Homero e Hesíodo. Esta mitopoética procura situar o alvo observacional a ser trabalhado na segundo parte, no poetar pensante dos chamados pré-socráticos.

Nesta, o fazer dos poetas é interrogado. 0 mito não é o puro mito em Homero e Hesíodo. A poesia desde já é um Logos para o mito. A reflexão de Anaximandro, Anaxímenes, Tales, Parmênides, Empédocles, Anaxágoras e Heráclito é a transformação desse logos em atividade diretiva de sua comunidade histórica. Pergunta-se agora pelos fundamentos desse logos. 0 logos do mito passa a instituir o mito do logos. Mas em um e outro modo de pensar, não se pensa senão pela provocação do que continua irredutivel a esta atividade. Pois ainda pensar é pensar-se, não como subjetividade que não se modifica com o que se propõe diante dela, mas como partícipe do jogo que insere o indivíduo na excedência de um acontecimento que representa a própria possibilidade de participação. Temos a dramatização da compreensão dos eventos.

A tradição sobre o logos do mito, sobre o logos encontra seu terceiro momento em Platão. Após excertos da poesia sobre o mito e os fragmentos mitopoéticos, nada mais complementar a esta interrogação grega sobre o saber tradicional que a obra Platônica. Aquele que em sua mocidade fora dramaturgo, impulsiona sua orientação mimética para o conhecimento dessa orientação. Os diálogos platônicos são estruturas dialogantes que interpretam a figuração. Eudoro escolhe em seu curso sobre a filosofia grega trechos que explicitam esta atividade. 0 tríptico da caverna, na República, a 
teoria da reminiscência em Menon, a fenomenologia da empatia em Lísis e a fala de Diotima no Banquete são representações da inteligibilidade interrogando o fundamento de sua possibilidade através do relato, da figura e da imagem. Ao invés da visagem da filosofia com catarse do mimético, temos aqui a mediação representacional como única tarefa a ser realizada e única coisa a se meditar. Aplica-se, neste momento a irônica conclusão que Heráclito observava no envolvimento dos sujeitos com a compreensão da realidade: “quem não espera o inesperado nunca o achará; que este é inexplorável e inacessivel" (fr. 18).

Continuando o curso, na quarta e última parte temos Aristóteles. Ele comparece com trechos de Metafísica e De generationem animalium. A pulsão organicista e classificadora que engendra a atividade gneseológica de Aristóteles depara-se com o silêncio do nome frente ao que não se deixa substancializar. Eudoro escolhe textos que, movimentando-se entre a descontinuidade dual do homem e a enumeração das partes desse todo buscado, surpreendem-se suspendendo-se frente ao incognossivel, frente ao indemonstrável que pode ou não ser chamado de deus. (Conf. fr. 32 de Heráclito: “Só um - o Sábio único- quer e não quer ser chamado pelo nome de Zeus"). Ou seja, no limite limitante da racionalidade irrompe uma infinitude que é complementar à pulsão cognoscente. 0 ímpeto da distinções que reverberam uma polêmica de base cada vez mais refinada retoma, a cada momento, a franja de indeterminação que acompanha todo processo construtor de sentido (Husserl). A trama dos diferidos enlaça à sua realização a presença dessa ausência fundante. A fenomenologia da estrutura da compreensão em Aristóteles advoga uma abertura ao factível. 0 pensar recai em uma vertigem classificatória ad infinitum quando elide esta situação pré-figuradora. A prefiguração como ato constitutivo da representação da realidade nada mais que é a extensividade finita da configuração de um saber que sempre atualiza seu contexto produtivo. Assim, entende-se a necessidade de Aristóteles em sua discussão a respeito das causas da matéria reivindicar a presença e a necessidade do primeiro motor, eterno, da inteligência divina. (Metafísica 1070).
Então a reverência aos eternos-grandes-outros na cultura grega faz com que se reveja este o simulacro do trajeto linear, progressivo do mito ao logos. Pois para melhor compreendermos a relação da Filosofia grega com a moderna, é preciso que se entenda a grega como razão com uma tarefa. A tensão entre mito e logos transformamos, pelo acontecimento da subjetividade em nossa História , em tensão entre ficção e realidade. Eudoro bem viu que a tarefa do pensamento na Hélade era estar diretamente relacionada com a vigência de um saber tradicional que toma da representação sua exemplaridade e modelização. Como resultado de seu curso sobre a Filosofia grega, ao invés de sucessivas expurgações dessa memória das situações, da reproposição dos contextos produtivos, vemos que a poética enfabuladora de Homero e Hesíodo, a mitopoética dos pré-socráticos, a dramaturgia platônica e a morfologia aristotélica são pontos convergentes para uma mesma problemática: a relação entre evento e recepção, entre o fazer dos fatos e sua compreensão. Teoria-ver-drama ! A genealogia suporta sua hermenêutica.

Novamente o jogo, a mímesis toma o centro. $\mathrm{Na}$ modernidade, E. Fink, Wittegenstein, Heidegger e Gadamer vão se ocupar dessa presença. E nós, para efeito da exigüidade de espaço e da extensão do tema, vamos nos ocupar dos dois últimos pensadores citados.

«0 que Heráclito chama de logos e o que ele pensa nessa palavra é o mais obscuro da palavra desse pensador" (HEIDEGGER, 1998, p. 255). Nesta afirmativa, Heidegger sintetiza seus vários anos de exegese da obra de Heráclito, como podemos ver especialmente nos comentários sobre o fragmentos 50 e 60, que versavam sobre o lógos e sobre Aletheia, nas preleções "A origem do Pensamento Ocidental (1943)” , “Lógica. A doutrina heraclítica do lógos (1944)" e no seminário de inverno 1966/1967 com E. Fink. Acompanhando a preleção " A origem do pensamento 0cidental" vamos reencontrar nosso tema.

Para Heidegger, pois, o que se desentranha da leitura e reflexão dos fragmentos é uma opacidade ao pensamento, opacidade quando este não se integra ao relato que o sustenta. De Heráclito se pode dizer o mesmo de um texto dramático, o qual nunca está 
desvinculado de seu dramatização. As falas são as rubricas da cena. A palavra final sobre os fragmentos será sempre uma redução se não levar em conta esta experiência representacional que atualizam. A hesitação entre a opção mimética e a tradução conceptual, que doa o efeito de um estranhamento à recepção da obra de Heráclito, está no intérprete. 0 contradito desempenhado se atualiza na estrutura da realidade pela convivência da perspectiva limitada do representado e pelo movimento de integração da representação.

Não é à toa que Heidegger escolhe para seus comentários sobre Heráclito duas anedotas. Da estória ascendemos à História (Guimarães Rosa). Em Aristóteles (De part. Anim., A5 645 a 17 ff.) temos a primeira anedota: "diz-se (numa palavra) que Heráclito assim teria respondido aos estranhos vindos na intenção de observá-lo. Ao chegarem, viram-no aquecendo-se junto ao forno. Ali permaneceram, de pé ( impressionados sobretudo porque) ele os (ainda hesitantes) encorajou a entrar, pronunciando as seguintes palavras: ' Mesmo aqui, os deuses também estão presentes.' “

Mais que a etiologia de um fragmento, aqui se representa a assimetria entre a expectativa da anônima platéia e a personagem Heráclito. Eles divergem quanto ao proceder da prática cultual. "Heráclito lê nas suas fisionomias a curiosidade decepcionada" (HEIDEGGER, 1998, p. 23). Os atos de Heráclito são interpretados pelos anônimos como que "marcados pelo caráter de exceção, raridade excitação, por oposição à vida cotidiana" (HEIDEGGER, 1998:22-23). A oposição está no modo como se participa de uma situação a qual, pela reposição dos atos, conserva certa orientação habitual. 0 não habitual do comportamento de Heráclito parte da mudança dessa orientação, fundamentando-se, logo, no habitual. 0 proceder de Heráclito, “como um olhar a tal ponto compenetrado no ordinário que, atravessando-o e perpassando-o, é o próprio extraordinário que se expõe na dimensão do ordinário. (HEIDEGGER, 1998: 24)", é um estranhamento que se interroga pelo Mesmo. No inaparente do cotidiano ali está o que se julgava impossível. Este olhar de Heráclito, contraposto à admiração decepcionada da platéia, é o olhar teórico, que designa "no sentido genuíno da palavra o theoros é, pois, o espectador que, através do tomar-parte, participa do ato festivo e, através disso, ganha sua distinção de direito sagrado"(GADAMER, 1997, p. 206).

Heráclito é o theoros, corista-dialogante da realidade representada em sua tensão compreensiva. Não agindo como se espera, Heráclito atua sobre a recepção. As palavras que diz após o drama do olhar assinalam que a dissonância cognitiva é porta-voz de um déficit de entendimento. Se os anônimos não compreendem que ele cultua o mesmo deus junto ao forno, ao invés de orar no templo, não conhecem seus atos, não ganharam com sua constante atividade um saber sobre seu fazer. 0 prélio entre os divergentes nos diz mais que diferença de opiniões. Incide sobre a participação naquilo que divergem. "Mesmo aqui os deuses estão presentes" ecoa como o logos de uma situação que nos diz mais que a pontualidade do momento. A assertiva interroga-se sobre a gênese de nossas práticas, sobre 0 vínculo com os contextos. Se não conseguem perceber que em outro espaço realiza-se o mesmo culto, significa que o culto mesmo carece de realidade ao se localizar no exíguo topos do já sabido. 0 que os anônimos estão perdendo, ironicamente, é o lugar, é o ponto-origem, o horizonte da participação, a situação que os dramatiza.

A segunda anedota é inversão da primeira, complementar encenação do mesmo drama. Lá conta-se que Heráclito “dirigiu-se, porém, ao santuário de Ártemis para lá jogar dados com as crianças; voltando-se aos éfesos que se puseram ao pé ao seu redor, exclamou: seus infames, o que estão olhando espantados? Não é melhor fazer o que estou fazendo do que cuidar da Pólis junto com vocês?"( HEIDEGGER, 1998, p. 25)

Nesta cena temos novamente os mesmos personagens mas agora dispostos na intensificação do conflito anteriormente representado. Se antes o anônimo não via no cotidiano o sagrado e estranhava, agora no sagrado estranha o cotidiano. Antes, longe do sacro lugar não viam o divino atuar; em após, no coração da deusa, não vem nada de religioso nos jogos. Ao contrário, vêem neste inútil divertir uma profanação. Novamente sob este olhar que se aguçou em desentendimento frente ao evento extracotidiano, Heráclito interfere mas com ira. Antes podiam não ter percebido a proximidade com o sagrado, pois o sagrado não estava em próprio lugar. Mas 
agora dentro do templo não conseguem perceber que os divinos não deixam de nos assistir?

0 tempo da vida, crianças brincando. A participação que exige uma modificação da subjetividade não ignora o fazer como saber, como saber-se. "Um pensador de quem se espera seriedade e profundidade ocupa-se com jogos infantis". (HEIDEGGER, 1998, p. 26). Seu pensar interroga a natureza dos vínculos, frente ao conhecimento/ desconhecimento do acontecer das realizações. 0 jogo Heráclito não o joga somente com as crianças e elas com ele. Joga com a comunidade, com os anônimos em sua volta, com a platéia. 0 que se apresenta é mais do que se representa, "é um representar de tal modo que apenas o representado é" (GADAMER, 1997, p. 191). As falas de Heráclito são a legibilidade dessa representação. 0 jogo representa-se como jogo, como disposição de uma realidade a partir de sua configuração. Pensar o jogo, é pensar a mímesis, pensar o que se representa, é representar o pensamento envolto em sua situação de mímesis.

A mímesis em Heráclito é dramática. Por sempre partir de uma situação, vendo que "todo presente tem seus limites" (GADAMER, 1997, p. 451), Heráclito conjuga drama e representação da realidade. Sabe bem que o pensar é uma experiência que toma desta atividade a matéria para sua expressão. 0 jogo é o logos de uma experiência na qual se aprende os limites de uma situação pela sua possibilidade expressiva. Aqui o logos é a dramatização das capacidades interpretativas do jogador. Heráclito jogou este jogo, pensou este logos.

Gadamer, interrogando-se sobre a compreensão humana, também vai pensar esse logos que se representa e se dramatiza. Vai pensar o drama através do jogo. Vai pensar o jogo do logos. A estrutura do jogo é a estrutura do logos. Não há pensamento sem situação, sem dramatização de uma experiência, que entre os gregos, por Heráclito, é experiência teórica, como vimos.

0 sucesso de uma filomitia ou de uma mitosofia em Atenas no século V a.C. (veja- se o caso de Platão e da tragédia), que chegou até nós na atividade hipercrítica racionalista e irracionalista, autoriza-nos a desconfiar da existência do seguinte fato: formas não discursivas guardavam um tipo de conhecimento que mesmo o criticismo sofista não conseguiu eliminar.

Que o mito se represente em uma tragédia ou se faça a comédia da razão, é algo que nos interessa pela presença do que continua rondando a História. Daquilo que não basta apenas falar e discorrer, constitui-se como saber que perdura. E como memória, representa-se.

0 fato é que para o que existia como condição de historicidade ainda não se inventou outro meio senão participar, através de reiterada atualização. 0 que é, só permanece porque vincula. E isso não é uma descoberta, é um acatamento.

A História nasce como tradição da qual nosso somos uma vulgata (VEYNE, 1987, p. 21), corrigindo e completando essencial e eventualmente. Esta dimensão correlativa não nos faz perguntar se isso é verdade, se isso existe. $\mathrm{Na}$ partilha e na incursão do sujeito naquilo que ele não é mais que se torna o fundamento de sua mundividência vive-se. 0 alvo determina 0 efeito; quem não buscar, soçobra.

0 mito, aquele outro mundo que não este, o extracotidiano se apresenta como interlocutor que não cessa de permanecer distante. É como acontecimento que o mito é presente, indevassável fronteira rigorosamente colocada entre nós e o que nos limita. E isto não é uma ideia. Trata-se de uma situação. Heráclito sabia disso. Eudoro de Sousa também. 0 logos nos apela para este drama. Mesmos são os caminhos que descem e sobem ( Heráclito, fr. 60) pois o revezamento dos transeuntes só se faz pela vigência do percurso.

A cena se abre diante nós, como realidade constituída, após mais de dois mil e quinhentos anos. Ironicamente, a mímesis fundamenta o logos, como bem Eudoro de Sousa observou e descreveu em Horizonte e complementaridade. A teoria, o olhar pensante que ronda o 0cidente, é o teatro de sua figuração.

Ironicamente, então, é a Tradição sobre a mímesis que subage na Cultura 0cidental (AUERBACH 1987). 


\section{Texto 4}

Notas para Prefácio a uma possivel nova edição de Filosofia Grega e Sempre o mesmo acerca do mesmo ${ }^{11}$

Os dois textos aqui reunidos - Filosofia Grega e Sempre o mesmo acerca do mesmo - são complementares, para usar uma conceituação mui cara a Eudoro de Sousa (Lisboa, 1911; Brasília, 1987). Eles atualizam um momento maduro na carreira do filósofo e pensador luso-brasileiro, no qual não só o estilo de escrita como também a amplitude das ideias encontra sua íntima conexão.

0 caminho para as duas obras que ora são publicadas é antecedido por diversos textos e pesquisas diretamente relacionadas com uma contínua preocupação em formar pesquisadores que integrem conhecimento de línguas clássicas e complexas discussões filosóficas, com uma ênfase em aspectos da tradição clássica que não hegemônicos, como a questão da mitologia. Dessa fase, são testemunhos sua conhecidíssima tradução comentada de $A$ Poética, de Aristóteles (Globo, 1966); o conjunto de ensaios de Dioniso em Creta e Outros ensaios. Estudos sobre Mitologia e Filosofia na Grécia Antiga (Duas Cidades, 1973); a tradução comentada de As Bacantes (Duas Cidades, 1974); e a síntese de seu pensamento em Horizonte e complementariedade: ensaios sobre a relação entre mito e metafísica nos primeiros Filósofos Gregos (Duas Cidades, 1976).

Note-se a intensidade de escritos durante a década de setenta do século passado. Os diversos trabalhos dessa década convergem para Horizonte $e$ Complementariedade, ao qual as publicações deste livro estão diretamente relacionadas: Filosofia Grega é um conjunto de notas e traduções para um seminário sobre a permanência e transformação de questões míticas e existenciais na formação do pensamento de Platão e Aristóteles; já Sempre o mesmo acerca do mesmo é um outro seminário, a partir do primeiro, com ênfase não na discussão e comentário de textos e sim nos pressupostos e questões que amparam tanto a escolha dos textos quanto dos temas que deles emergem.

Assim sendo, Filosofia Grega e Sempre o mesmo acerca do mesmo colocados frente a frente são livros irmãos, mas organizados de modo completamente diverso.

Isso só se torna compreensível quando se entende a trajetória intelectual de Eudoro de Sousa. 0 contraste entre esses livros irmãos, publicados no mesmo ano de 1978 como textos de seminário de extensão, explicita a redefinição das opções expressivas e das preocupações e obsessões temáticas de Eudoro de Sousa que agora, no lugar de levantar fontes para suas afirmações ou de propor sínteses a partir de suas investigações, movimenta-se no terreno do ensaio, da metarreflexão, no intercruzamento entre escritura, antropologia, história e mito. Se a década de 1970 do século passado testemunha o hercúleo esforço de leituras e bibliografias que coloquem em primeiro plano referências subterrâneas nos Estudos Clássicos, como uma reação ao positivismo e atomismo redutor que dominava a área, o fim desta mesma década e os albores da década seguinte, com a publicação de Mitologia (Editora Universidade de Brasília, 1980) e História e Mito (Editora Universidade de Brasília, 1981), fazem irromper um outro Eudoro de Sousa - a do pensador, a do estilista, que se movimenta-se por entre suas fontes, para além do papel de professor, para além de seu circuito imediato de colaboradores. Não é à toa que no prefácio de Mitologia ele venha a afirmar que "e assim me despeço deste meu livro, porque outro, apenas sonhado, já me insta para que o pense e escreva, ou antes, para que o escreva e pense, pois, na verdade, eu só penso quando escrevo."

Assim sendo, os dois livros aqui reunidos são importantes documentos que registram as metamorfose na trajetória intelectual de Eudoro de Sousa. Filosofia Grega se divide em duas partes: na primeira temos trechos traduzidos de poetas (Homero, Hesíodo, entre outros), do chamados filósofos presocráticos (Anaximandro, Parmênides, Heráclito, Xenófanes, Empédocles) e comentaristas dos temas abordados. São como notas de aulas das quais não temos o texto principal. Há uma forte dependência quanto ao livro Horizonte e Complementariedade, com referência aos textos de lá retomados. É como se fosse uma coletânea de Horizonte e Complementaridade. Ou sua ampliação: pois
11. Texto apresentado ao Colóquio 100 anos de nascimento de Eudoro de Sousa, Universidade de Brasília, 2011. 
agora são apresentadas traduções mais completas de pelo menos dois autores - Empédocles, Parmênides e Heráclito. Só a disponibilização das traduções já vale a publicação Filosofia Grega.

Lembrar que este esforço tradutório em disponibilizar as fontes para o estudos da antiguidade faz parte do percurso intelectual de Eudoro de Sousa. Em anexo, como demonstração disso, segue o precioso documento Centro de Estudo das Línguas Culturas Clássicas, no qual se apresentam as diretrizes para um centro interdisciplinar para acesso e problematização da Antiguidade. A lucidez do texto escrito em 14 de maio de 1962 projeta um debate atual sobre a inserção da cultura clássica na universidade, tanto nos modos de sua implementação, quanto na discussão conceptual que determina ações concretas.

Ainda ratificando como a década de setenta do século passado e a publicação de a Filosofia grega faz emergir, Eudoro publicou pela Revista Brasileira de Filosofia em 1954 dois grandes artigos intitulados “Fontes da História da Filosofia Grega", dos quais grande parte do material presente em Horizonte e Complementariedade e Filosofia grega são devedores.

0 que fica patente nessa genealogia é que 0 empenho filológico e educativo de antes possibilitou o vigor ensaístico posterior. A detida análise e tradução das fontes, como se vê nos artigos de 1954, calcados na edição de Diels-Kranz, foi o ponto de partida, o estímulo para as argumentações e explorações filosóficas nas décadas seguintes.

Logo, munido de fontes, das bibliografias primárias e dos melhores comentaristas, Eudoro foi ampliando o espectro de suas atividades: de uma convergências e filtro de temas da cultura clássica para se tornar em um autor, em bibliografia mesmo. Esse passo ele chegou ao debater as relações entre filologia e filosofia, entre leitura de textos e sua recepção.

A segunda parte de Filosofia Grega testemunha isso: a escolha dos textos traduzidos e seu comentário redimensiona as fontes. Ao se revisar historiografias tradicionais da filosofia que parte do trajeto linear “Do mito para a filosofia", perpetuando uma imagem de superação do primeiro termo pelo segundo, Eudoro tanto evidencia que o estudo do texto precisa estar vinculado ao debate da ideias, quanto propõe possibilidades de interpretação desse trajeto linear.
Sempre o mesmo acerca do mesmo vai explicitar o que em Filosofia Grega parece críptico, não demonstrado por palavras. Mas sem perder a perspectiva elusiva, o contexto de metamorfose que agora se desenha. Se Filosofia Grega é uma coletânea de textos para aula sem que haja um texto central que unifique e comente tudo o que foi disponibilizado, Sempre o mesmo acerca do mesmo é um conjunto de ensaios para um seminário que é interrompido, um diálogo que não cumpre sua pretensa meta de docência. 0 livro se abre com dois questionários de Ordep Serra, querido e profícuo classicista, na época aluno de Eudoro de Sousa. Como aluno do seminário proposto, Ordep Serra demanda do mestre algumas respostas. As respostas ao primeiro questionário deixam Ordep insatisfeito. Daí um segundo, que é intitulado pelo impaciente mestre "uma resposta ao $2^{\circ}$ questionário de ordep serra ainda sem intuito de responder diretamente a todas as questões".

Reiterando seu destino de escritura, Eudoro prefere nesse momento mais leitores. A organização de Filosofia Grega e Sempre o mesmo acerca do mesmo atesta isso. Tanto que esse voltar-se para sim mesmo, para a expressão, determinou também um expressão mais cativa de sua própria elaboração, aproximando o escritor Eudoro de Sousa de sua obsessão escritural: o vigor do mito.

Nesse sentido, devolvemos ao leitor as obras que Eudoro a eles dedicou.

\section{REFERÊNCIAS BIBLIOGRÁFICAS}

AUERBACH, E (1987). Mímesis. São Paulo, Perspectiva. GADAMER, H.G. (1997). Verdade e Método. Petrópolis, Vozes. HEIDEGGER, M. (1998). Heráclito. Rio de Janeiro, Relume Dumará.

ISER, W. (1998). 0 ato de ler. Rio de Janeiro: Editora 34, 1996. MOTA, M. Imaginação Dramática. Brasília, Texto\&Imagem.

(1998). Ler e depois. Brasília, Texto\&Imagem.

(1992). " 0 diferencial da diferença: A Alethopoiesis de Ronaldes de Mello e Souza" Anais do 3. Congresso da Abralic. São Paulo: Edusp, p. 607-612.

NIETZSCHE, F. (1995). A filosofia na idade trágica dos gregos. Lisboa, Elfos.

SOUSA, E. de (1973). Dioniso em Creta e outros ensaios. S. Paulo, Duas Cidades. 
(1978 (A)). Filosofia Grega, Brasília, Editora UnB. (1980). Mitologia. Brasília, Editora UnB. Editora UnB.

(1981). História e mito (Mitologia II). Brasília,

(1978 (B)). Filosofia grega, Brasília, Editora UnB. (1978 (C)) 0 mesmo acerca do mesmo. Brasília, Editora UnB.

Duas Cidades.

(1975). Horizonte e complementaridade. São Paulo,

(1959). “Teísmo, cosmobiologia e o princípio da complementaridade". In. Anais do II Congresso Nacional de Filosofia. São Paulo, p. 491-498.

(1956). “Prolegômenos a uma filosofia da religião pré- helênica" In: Anais Congresso Internacional de Filosofia. São Paulo, IBF, p. 297-307.
(1962). Arqueologia do Egeu. Brasília, Manuscrito CEC/ UnB.

(1983). “Orfeu ou acerca do conceito da filosofia antiga". Revista Brasileira de Filosofia. 163, pp 384-399.

(1974). As Bacantes. São Paulo, Duas Cidades.

VEYNE, P. (1989). Acreditavam os gregos em seus mitos? Lisboa, Edições 70.

Recebido em novembro de 2011. Aprovado em dezembro de 2011. 